\title{
DATA BARU TENTANG KAMPUNG KAUMAN YOGYAKARTA STUDI BERDASARKAN TEMUAN ARTEFAKTUAL
}

\section{NEW DATA ON KAUMAN, YOGYAKARTA A STUDY ON ARTIFACTS}

\author{
Muhammad Chawari \\ Balai Arkeologi D.I. Yogyakarta \\ mchawari@yahoo.com
}

\begin{abstract}
Kauman is one of the oldest settlement and part of the bureaucratic structure of Yogyakarta's palace. The old buildings in Kauman were interesting topics to many research there. Mean while on the other hand, artifacts as anothersupporting data of the daily life there have never been revealed. This paper aims to look at the connection between the artifacts findings with the Kauman settlement as well as Yogyakarta's palace. Analytical descriptive method is used to describe and analyze the artifacts to see the development of Kauman itself.
\end{abstract}

Keywords: New data, Kauman village, Yogyakarta.

\begin{abstract}
ABSTRAK
Kauman Yogyakarta sebagai kampung lama dan merupakan bagian dari struktur birokrasi Kraton Yogyakarta. Di kampung tersebut terdapat banyak data arkeologi, terutama bangunanbangunan. Data-data tersebut sudah banyak diungkap, terutama kaitannya dengan pembuatan karya tulis ilmiah. Selain data yang berupa bangunan, terdapat data yang bersifat artefaktual. Data artefaktual inilah yang hingga kini belum pernah diungkap. Tulisan ini bertujuan untuk mengetahui kaitan antara data yang bersifat artefaktual tersebut dengan kraton secara umum dan Kampung Kauman khususnya. Metode yang digunakan adalah deskriptif analitik yaitu untuk menguraikan dan sekaligus menganalisis data arkeologi dimaksud. Data tersebut dapat memberikan gambaran tentang perkembangan yang terjadi di Kampung Kauman.
\end{abstract}

Kata kunci: Data baru, Kampung Kauman, Yogyakarta.

\footnotetext{
Tanggal Masuk : 25 April 2017

Tanggal Diterima : 29 November 2017
} 


\section{PENDAHULUAN}

Kauman merupakan salah satu nama kampung yang berada di Kelurahan Ngupasan, Kecamatan Gondomanan, Kotamadya Yogyakarta, Provinsi Daerah Istimewa Yogyakarta. Secara astronomis kampung ini terletak $110^{\circ}$ $21^{\prime} 32,4^{\prime \prime}-110^{\circ} 21^{\prime} 48,8^{\prime \prime}$ BT dan $7^{\circ}$ 48' 5,25" - $7^{\circ} 48^{\prime} 18,36 "$ LS. Kampung Kauman dikelilingi oleh jalan besar, yaitu sebelah utara merupakan Jalan K.H. Ahmad Dahlan, sebelah barat adalah Jalan Nyai Ahmad Dahlan, sebelah selatan berbatasan dengan Kecamatan Kraton yang berupa tembok keliling kraton (baluwarti), dan sebelah timur berbatasan dengan $\mathrm{Jl}$. Trikora dan Jalan Pekapalan, masingmasing terletak di bagian utara dan selatan (Chawari, 2008: 29).

Kauman merupakan nama yang sudah umum dan tidak asing lagi bagi masyarakat Yogyakarta. Kauman ini keberadaannya baik di kabupaten maupun kota bekas kerajaan Islam (misalnya Yogyakarta dan Surakarta). Yogyakarta sebagai ibukota Mataram Islam pasca Perjanjian Giyanti terdapat dua nama Kauman yaitu Kauman Gondomanan (Gm) dan Kauman Pakualaman (PA). Khusus Kauman Gondomanan merupakan kampung yang cukup penting dan strategis. Penting dan strategisnya Kauman, selain karena letaknya berada di sekitar nol kilometer Yogyakarta, juga hubungan sejarahnya dengan Kraton Kasultanan Yogyakarta. Demikian pula dengan Kauman Pakualaman juga mempunyai hubungan yang erat dengan Kraton Yogyakarta.

$$
\text { Selain itu, Kauman }
$$

Gondomanan (selanjutnya cukup disebut dengan nama Kauman) memiliki peran penting di masa lalu. Pentingnya Kauman di masa lalu dapat dilihat dari jumlah penelitian dan kajian yang kemudian menghasilkan karya tulis ilmiah. Terdapat beberapa karya tulis ilmiah hasil penelitian tentang Kauman, baik Kauman sebagai kawasan hunian lama, maupun bagian-bagian dari kampung ini. Beberapa tulisan yang dapat diketengahkan antara lain skripsi tentang Masjid Besar berjudul "Pasang Surut Masa Perkembangan Pembangunan Masjid Besar Kauman Yogyakarta: Studi Berdasarkan Sumber Prasasti”. Tulisan tersebut bertujuan untuk mengungkapkan pentahapan pembangunan Masjid Besar Kauman Yogyakarta berdasarkan situasi politik dan keadaan sosial ekonomi Kraton Yogyakarta melalui inskripsi-inskripsi yang ada di masjid tersebut. Berdasarkan inskripsi-inskripsi tersebut dapat diketahui waktu pendirian bagian-bagian dari masjid tersebut serta masa pemerintahan para sultan di Kraton Yogyakarta (Chawari, 1989: 7 dan 122 - 124). Tulisan berikutnya berupa tesis tentang Kauman berjudul "Pola Spasial Permukiman di Kampung Kauman Yogyakarta". Tesis tersebut bertujuan untuk mendapatkan gambaran tentang keragaman pola spasial permukiman secara mikro yaitu perumahan dalam kaitannya dengan sirkulasi, ruang terbuka, dan fasilitas lingkungan; serta secara mikro yaitu pola spasial kelompok permukiman. Secara spasial di Kauman terdapat tiga kelompok permukiman, yaitu kelompok rumah dan kompleks pengulon, kelompok rumah khotib (ketib), dan kelompok rumah pengusaha batik (Mulyati, 1995: 10 - 11 dan 136). Berikutnya adalah tesis yang berjudul "Bangunan Rumah Tradisional Jawa Di Kampung Kauman Yogyakarta: Sebuah Model Pengelolaan". Karya tulis tersebut bertujuan untuk mengetahui karakter bangunan-bangunan dan mengetahui sejauh mana karakter-karakter 
tersebut dapat mencerminkan bahwa kawasan Kauman layak untuk dilestarikan. Setelah itu membuat model pelestarian dan pemanfaatannya (Chawari, 2008: 8). Terakhir adalah disertasi berjudul "Pemufakatan Dan Desakralisasi Ruang Di Permukiman Kauman Yogyakarta". Karya tulis ini bertujuan untuk melihat fenomena keruangan secara empiris, menggali dan memahami latar belakang yang mendasari munculnya fenomena tersebut. Pemufakatan ruang adalah tindakan bermufakat pada ruang dalam hal mengelola, memanfaatkan, dan memakai ruang dalam waktu yang terbatas. Sedangkan desakralisasi ruang adalah tindakan menghilangkan sifat keramat, sakti, dan sakral pada ruang (Triatmodjo, 2010: 13 dan 398).

Sesuai dengan uraian di atas terdapat dua catatan tentang Kauman Yogyakarta, yaitu keberadaan Kampung Kauman berkaitan erat dengan Kraton Kasultanan Yogyakarta. Selain itu, Kauman merupakan kampung yang sangat padat penduduk dan terletak di sebelah barat daya nol kilometer Yogyakarta. Daerah ini terletak di sisi barat garis sumbu filosofi, yaitu berada di sebelah utara kraton Yogyakarta. Garis sumbu filosofi merupakan garis lurus yang membentang antara Tugu Pal Putih Kraton - Panggung Krapyak (Suwito, 2016: 6 - 9). Kekunoan kampung ini terletak selain karena sejarahnya, juga dapat dilihat dari banyaknya bangunan rumah tinggal yang merupakan bangunan tradisional Jawa (Chawari, 2008: 81 - 117). Sementara data artefaktualnya hingga saat ini belum pernah diungkap. Selain itu, data tersebut (artefaktual) belum pernah ditemukan.
Pembahasan atau kajian yang pernah dilakukan selama ini tentang Kauman Yogyakarta utamanya berkisar pada aspek tata ruang, karakter bangunan kuna, maupun sejarah. Sementara data tentang kehidupan keseharian yang dicerminkan antara lain dari temuan artefak di Kauman Yogyakarta belum pernah dibicarakan, karena sejauh ini belum pernah diteliti tentang artefak dari situs Kauman. Hal ini yang akan dicoba untuk dijawab dari pembahasan tentang data artefak yang ditemukan di Kauman beberapa waktu yang lalu.

\section{METODE}

Metode penelitian dalam karya tulis ini adalah deskriptif analitik, yaitu dengan cara menguraikan dan sekaligus menganalisis data artefaktual yang berasal dari Kauman. Dengan menggunakan kedua cara tersebut secara bersamasama, diharapkan objek yang dibahas dapat memberikan makna secara maksimal (Ratna, 2010: 336). Dalam pelaksanaannya dilakukan beberapa kegiatan, yaitu deskripsi, analisis, dan interpretasi data arkeologi. Ketiga kegiatan tersebut berkaitan dengan upaya melakukan interpretasi baru terhadap berbagai macam informasi data lama untuk mendapatkan informasi baru (Tanudirjo, 1988 1989: 18 - 35). Berdasarkan atas ketiga tahapan tersebut, hasilnya diarahkan untuk memberikan gambaran tentang objeknya, baik dalam kerangka waktu, bentuk, maupun keruangan.

\section{HASIL PENELITIAN}

Seperti telah disampaikan di atas, data baru tentang Kampung Kauman Yogyakarta merupakan data arkeologi yang bersifat artefaktual. 
Salah satu difinisi data artefaktual adalah data arkeologi yang berasal dari unsur alam yang sudah dimodifikasi oleh manusia secara sengaja dalam rangka untuk memenuhi kepentingan hidupnya dan merupakan benda bergerak (Anonim, 1994: 5). Sifat data arkeologi yang demikian ini menyebabkan objeknya dapat dengan mudah dipindahpindahkan dari satu tempat ke tempat lain, baik yang disengaja maupun tidak disengaja.

Sebelum memaparkan seluruh data artefaktual yang dimaksud, terlebih dahulu akan disampaikan secara ringkas riwayat penemuan data tersebut. Beberapa waktu yang lalu yaitu sekitar awal tahun 2013 salah satu rumah di Kauman yang beralamat di Kauman Gm I No. 244 (RT. 49, RW. XIII) sedang diperbaiki. Dalam kegiatan tersebut salah satu yang dilakukan adalah pembuatan lubang untuk fondasi tiang bangunan. Dalam proses menggali lubang tersebut telah ditemukan beberapa artefak, yaitu pada kedalaman antara 1,5 s.d. 2 meter. Secara umum artefak yang ditemukan dapat dikelompokkan dan dipilah ke dalam tiga jenis, yaitu: gerabah, fragmen keramik, dan fragmen kaca. Temuan tersebut adalah:

\section{Gerabah}

Gerabah yang ditemukan seluruhnya berjumlah enam dan terdiri atas yang utuh dan tidak utuh.

a. Gerabah utuh

Temuan gerabah yang utuh berjumlah satu berupa kendi.

b. Gerabah tidak utuh, berjumlah 5 buah terdiri atas 3 buah fragmen tepian, 1 buah fragmen dasar, dan 1 buah figurin.

\section{Fragmen Keramik}

Fragmen keramik yang ditemukan seluruhnya berjumlah 68 dan terdiri atas keramik utuh, tidak utuh, dan kelereng.

a. Keramik utuh

Temuan keramik yang utuh berjumlah satu berupa mangkuk kecil.

b. Fragmen keramik tidak utuh, berjumlah 64 buah terdiri atas 2 buah fragmen tutup, 35 buah fragmen tepian, 10 buah fragmen badan, dan 17 fragmen dasar.

c. Kelereng

Temuan keramik yang berupa kelereng berjumlah tiga buah.

\section{Fragmen Kaca}

Fragmen kaca yang ditemukan seluruhnya berjumlah 10 buah, terdiri atas yang utuh dan tidak utuh.

a. Kaca utuh

Temuan kaca yang utuh berjumlah satu dan berupa botol.

b. Fragmen kaca tidak utuh, berjumlah 9 buah terdiri atas 5 buah fragmen tepian, 3 buah fragmen badan, dan 1 fragmen dasar.

\section{DISKUSI DAN PEMBAHASAN}

Temuan data artefaktual dari Kauman Yogyakarta terdiri atas: gerabah, keramik, dan kaca. Di bawah ini akan diuraikan hasil analisis masing-masing jenis artefak.

Analisis temuan gerabah akan memakai pedoman Buku Panduan Analisis Keramik. Sebab istilah keramik dipakai untuk menyebutkan semua barang tanah liat yang dibakar, yaitu tembikar (earthenware), batuan (stoneware), dan porselin (porcelain) (Rangkuti dkk, 2008: iii). Dalam analisis tersebut dipakai pedoman analisis atribut teknologi yang berhubungan dengan teknologi pembuatan mulai dari pengolahan bahan sampai dengan pembakaran 
(Rangkuti dkk, 2008: 28). Secara umum temuan gerabah ini dapat dipisah menjadi dua jenis, yaitu yang utuh dan tidak utuh. Temuan utuh berupa kendi sebanyak satu objek. Benda ini dibuat dari bahan yang berupa tanah liat dan tanpa bahan campuran. Berdasarkan atas irisannya diketahui bahwa tanah liatnya bertekstur halus. Karakter lainnya pada gerabah halus yang berupa kendi tersebut memiliki slip. Selanjutnya berkaitan dengan pembakaran, diketahui bahwa gerabah halus ini tingkat oksidasinya merata. Oksidasi adalah reaksi dengan senyawaan yang mengandung oksigen $(\mathrm{C}+\mathrm{O} 2 \rightarrow \mathrm{CO} 2)$ (Shadily, 1983: 2429). Tidak ada hiasan atau dekorasi pada seluruh permukaan kendi atau merupakan kendi polos dan memakai semacam glasir berwarna coklat tua kehitaman. Glasir adalah lapisan bening dan mengkilap mirip kaca dan dipakai untuk melapisi barang-barang tembikar (gerabah), keramik atau porselen supaya menjadi lebih indah (Shadily, 1980: 1135).

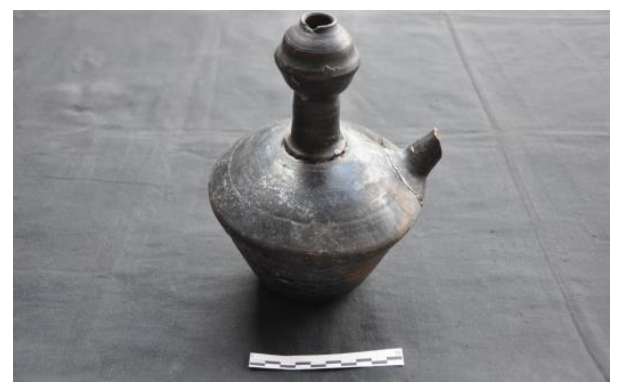

Gambar 1. Temuan Kendi yang Utuh dan Polos Tanpa Hiasan

(Sumber: Dokumentasi Penulis)

Secara khusus kendi ini merupakan wadah yang dindingnya tipis, dibanding dengan gerabah lainnya yang ditemukan. Temuan data yang lain berupa fragmen figurin. Fragmen ini adalah bagian dari arca atau patung yang merupakan bagian dari pundak dan sebagian lengan yang tampak memakai kelat bahu.
Fragmen ini dibuat dari bahan tanah liat. Berdasarkan atas irisannya diketahui bahwa tanah liat tersebut masih kasar dan tidak disaring serta tanpa bahan campuran, sehingga terlihat kasar. Sebab dari temuan yang ada, terdapat gerabah halus dan kasar. Selain itu, yang berkaitan dengan pembakaran diketahui bahwa fragmen ini tingkat oksidasinya merata. Secara umum barang-barang yang dibuat dari gerabah maupun keramik mempunyai fungsi yang sama yaitu digunakan untuk peralatan dan perlengkapan kehidupan yaitu alat-alat rumah tangga. Fungsi sebagai peralatan rumah tangga di dalamnya terdapat fungsi sebagai hiasan atau dekorasi. Untuk hiasan atau dekorasi semacam ini salah satunya berbentuk miniatur manusia (Rangkuti dkk, 2008: 46 49) atau figurin.

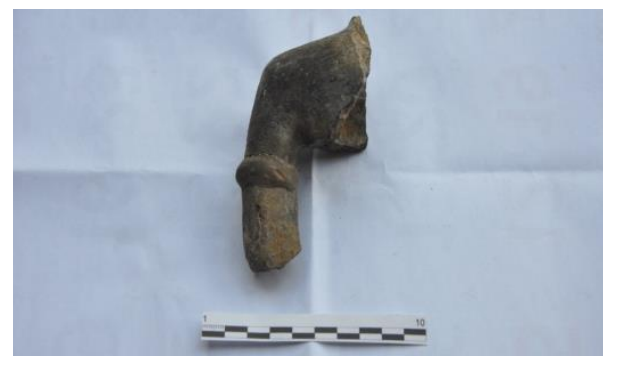

Gambar 2. Fragmen Figurin Dari Bagian Pundak dan Sebagian Lengan (Sumber: Dokumentasi Penulis)

Sementara itu, gerabah lain yang terdiri atas 3 tepian dan 1 dasar dapat dimasukkan sebagai gerabah kasar. Gerabah dengan jenis ini menggunakan temper berupa sekam dan pasir. Temper adalah bahan campuran yang antara lain terdiri atas pasir, pecahan karang, potonganpotongan kecil sekam padi atau hancuran tembikar yang tidak terpakai lagi (Rangkuti dkk, 2008: 1).

Karakter lainnya dari gerabahgerabah ini adalah tidak memiliki slip, dan pembakarannya sempurna dengan oksidasi merata. Salah 
satudari empat fragmen yang ditemukan mempunyai ketebalan antara 4,53 - 5,77 mm. Dengan ketebalan yangdemikian ini dapat dikatakan bahwa fragmen ini merupakan bagian dari suatu wadah yang bentuknya relatif tidak terlalu besar. Terdapat dua kemungkinan yaitu merupakan fragmen dari kuali atau pengaron. Selain itu terdapat satu fragmen yang merupakan bagian dasar dan berkaki. Fragmen ini kemungkinan merupakan cobek, yaitu suatu wadah yang salah satu fungsinya adalah untuk membuat sambal.

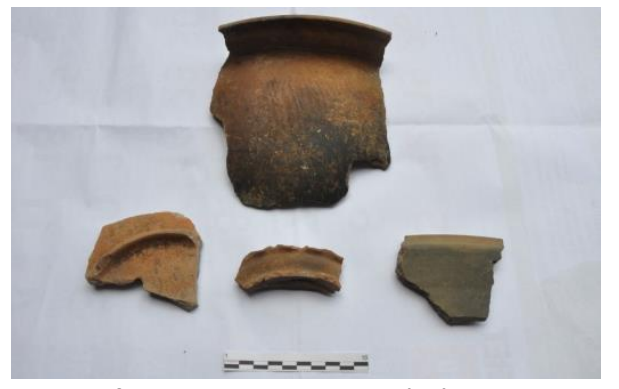

Gambar 3. Fragmen Gerabah Bagian Tepian dan Bagian Dasar dari Wadah

(Sumber: Dokumentasi Penulis)

Berdasarkan data-data di atas, jelas bahwa terdapat beberapa macam benda atau barang dari gerabah yang pernah digunakan masyarakat Kauman pada waktu itu, yaitu terdiri atas kendi, kuali atau pengaron, cobek, dan figurin. Secara umum kendi berfungsi sebagai tempat air minum, kuali atau pengaroh merupakan wadah untuk menampung air bersih, cobek merupakan alat yang diduga salah satunya berfungsi untuk membuat sambal, sedangkan figurin diduga merupakan bagian dari hiasan yang berupa patung.

Urutan kedua setelah fragmen gerabah adalah fragmen keramik. Secara umum seluruh temuan fragmen keramik yang ada dapat dikelompokkan menjadi tiga berdasarkan atas asal usulnya, yaitu fragmen keramik dari Jepang, Eropa, dan Cina. Khusus keramik Jepang diketahui berdasarkan atas hiasan yang ada di permukaan keramik. Hiasan tersebut berupa lukisan manusia berjenggot dengan tutup kepala dan matanya terkesan "sipit", dengan variasi warna biru tua. Lukisan tersebut berada pada lingkungan alam dengan pohon di sekitarnya. Keramik Jepang ini berukuran: garis tengah bagian atas antara 4,59-4,74 cm (tidak simetris), garis tengah bagian bawah (bagian kaki) antara 2,19 - 2,20 cm, dan tinggi antara 3,10-3,20 cm. Keramik ini dalam kondisi utuh dan merupakan wadah berbentuk mangkuk berukuran

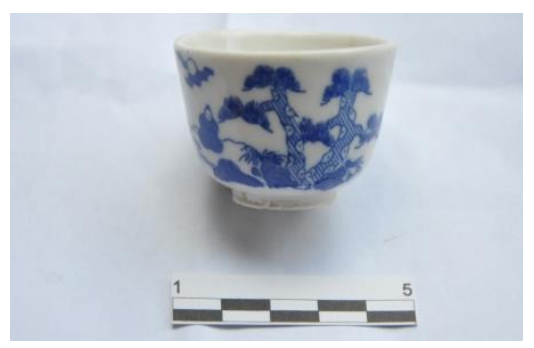

Gambar 4. Temuan Keramik yang Utuh Adalah Keramik Jepang, Berupa Mangkuk Kecil yang Berhias

(Sumber: Dokumentasi Penulis)

kecil. Melihat ukuran dan bentuk seperti tersebut di atas, diperkirakan benda ini digunakan untuk acara minum teh. Secara umum keramik atau porselen Jepang yang banyak ditemukan di Indonesia berasal dari paruh kedua abad XVII berupa piring, kendi, kotak, penutup mangkuk besar, dan botol-botol yang difungsikan untuk mencampur obatobatan. Keberadaan keramik Jepang di Indonesia tidak dapat dilepaskan dari perannya VOC. Hal ini terkait dengan usaha VOC dalam rangka mempertahankan kantor dagang nya di Pulau Kiushyu dekat Hirado (Jepang) antara tahun 1609 - 1641. Perdagangan keramik Jepang oleh 
VOC dihentikan secara resmi pada tahun 1683 (Adhyatman, 1990: 80 81).

Berikutnya keramik Eropa. Berdasarkan atas materi atau bahannya, keramik Eropa ini dapat dilihat berdasarkan atas kaolinnya. Kaolin adalah mineral lempung berwarna putih dan secara ekonomis cukup besar sebagai bahan keramik serta merupakan hasil ubahan atau pelapukan dari felspar atau mika (Shadily, 1982: 1651). Kaolin pada keramik Eropa pada umumnya memiliki partikel yang cukup halus dan teksturnya cukup rapat. Hal yang demikian ini agak berbeda dengan keramikdari daratan Cina. Diketahui keramik Cina memakai bahan batuan yang dicampur dengan kaolin. Keramik Eropa yang ada merupakan keramik yang tidak berhias, namun beberapa di antaranya memakai hiasan. Beberapa hiasan yang teridentifikasi adalah bunga, tumbuhan, floral, dan bangunan dengan warna biru tua. Selain itu, yang paling jelas tentang keramik Eropa ini karena adanya tulisan. Tulisan pada keramik Eropa ini terdapat pada bagian dasar piring kecil dan terdiri atas 4 baris, yaitu:

- Petrus

- Regout \& Co

- MAASTRICHT

- MADE IN HOLLAND

Sesuai dengan yang tertulis pada bagian dasar keramik, diketahui bahwa Petrus Regout merupakan perusahaan yang berasal dari Belanda.

Sementara itu, dari segi bentuknya dapat teridentifikasi. Mengingat data yang ditemukan berupa fragmen tepian, fragmen dasar, dan fragmen tutup dengan sedikit fragmen badan. Dari fragmen tepian, fragmen dasar, dan fragmen tutup tersebut dapat diketahui bahwa keramik Eropa tersebut terdiri atas beberapa bentuk, yaitu piring, mangkuk, cangkir (dengan pegangan), gelas, piring kecil, tutup cangkir, teko, dan tutup wadah.

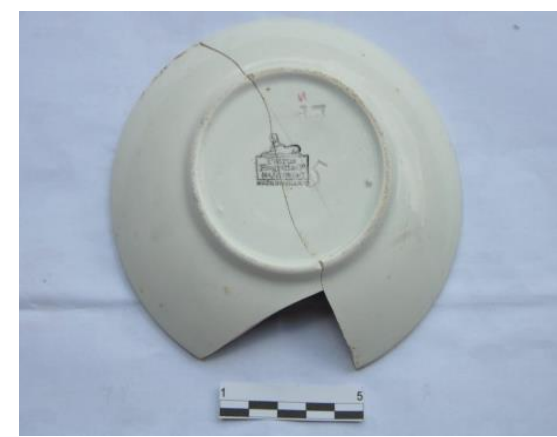

Gambar 5. Keramik Eropa dengan Tulisan di Bagian Belakang

(Sumber: Dokumentasi Penulis)

Selain keramik Eropa seperti diuraikan di atas, terdapat satu fragmen stoneware. Berdasarkan identifikasi bentuk diketahui bahwa satu fragmen stoneware tersebut berupa botol.

Fragmen botol ini berwarna coklat muda. Botol semacam ini banyak ditemukan di Kota Lama Semarang. Pada umumnya botol semacam ini digunakan untuk tempat air soda (Abbas, 2016: 20) yang didatangkan dari Eropa.

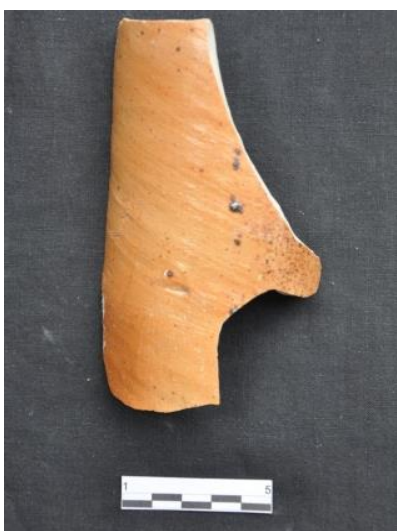

Gambar 6. Botol Dari Eropa Tempat Air Soda

(Sumber: Dokumentasi Penulis) 


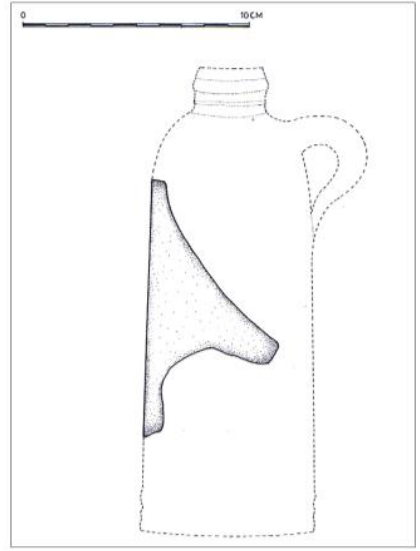

Gambar 7. Rekonstruksi Botol Dari Eropa Berdasarkan Temuan Seperti Pada Gambar no. 6

(Digambar oleh Tedy Setyadi)

Hal yang sama terjadi pada keramik Cina. Data tentang keramik Cina ini kebanyakan berupa fragmen tepian dan fragmen dasar dengan sedikit fragmen badan. Data tersebut (fragmen tepian dan fragmen dasar) dapat diketahui bahwa keramik Cina ini terdiri atas piring, mangkuk, dan mangkuk kecil. Keramik Cina ini sebagian besar berhias, namun ada satu fragmen yang polos. Terdapat beberapa hiasan, yaitu floral, garis putus-putus, garis yang menyambung, garis tipis, garis tebal, dan bunga (?). Terkait dengan hiasan terdapat beberapa warna, yaitu biru muda, biru tua, dan abu-abu kehijauan.

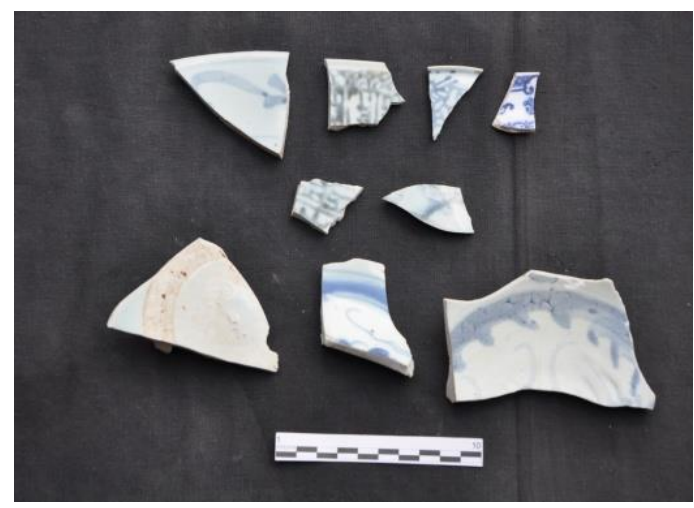

Gambar 8. Beberapa Fragmen Keramik Cina (Sumber: Dokumentasi Penulis)
Berdasarkan atas ciri-ciri tersebut di atas, diketahui bahwa keramik Cina ini berasal dari dua dinasti yang berbeda tetapi berurutan yaitu Dinasti Ming (1368 - 1644 M) dan Dinasti Qing (1644 - awal abad 20).

Pada masa Dinasti Ming terdapat beberapa peristiwa penting, yaitu:

$\checkmark$ Terjadinya beberapa peristiwa oleh rezim Mongol yang dipimpin Zhu Yuanzhang. Kemudian ia menyatakan dirinya sebagai kaisar Ming pertama.

$\checkmark$ Pada tahun 1551 Portugis diizinkan masuk ke Makau melalui pantai selatan, khusus untuk perdagangan perak, sutra, dan porselen.

$\checkmark$ Khusus yang terkait dengan kegiatan seni, yaitu yang dilakukan oleh pihak kekaisaran (paling dominan) dan pihak amatir. Para pengrajin terbaik ditunjuk untuk melayani kekaisaran dalam kegiatan-kegiatan resmi. Paling penting adalah adanya kebebasan dalam berekspresi, khususnya seni dalam pemberian hiasan pada barang-barang keramik biru-putih. Juga terkenal dalam kreasi baru, terutama dalam penggunaan bahan berkualitas tinggi oleh bengkel kekaisaran. Gaya kekaisaran yang kaya dan elegan diterapkan di semua media mulai dari arsitektur untuk lukisan, bahkan diperluas untuk desain peralatan sehari-hari ( $\mathrm{Li}, \mathrm{tt}: \quad 207-$ 208).

Selanjutnya pada Dinasti Qingyang merupakan kelanjutan dari Dinasti Ming juga mengalami hal yang hampir sama, yaitu antara lain:

$\checkmark$ Pada masa dinasti ini negara mengalami masa kemakmuran yaitu di bawah Kaisar Kangxi (1662-1722), Yongzheng (17231735), dan Qianlong (1736-1795). 
Ketiga kaisar tersebut mengadopsi ide-ide dari Barat.

$\checkmark$ Penguasa Dinasti Qing pasca tahun 1795 tidak lagi memiliki semangat dan kemampuan intelektual. Selain itu, setelah 1840 harus menghadapi masalah intern dan ekstern. Dinasti ini akhirnya tidak mampu bertahan dan harus menandatangani beberapa perjanjian, yaitu dengan Inggris (tahun 1842), dengan Perancis (tahun 1885), dan dengan Jepang (tahun 1895). Puncaknya adalah tahun 1911 dinasti ini runtuh.

$\checkmark$ Secara umum, seni mencapai standar yang tinggi dengan ornamen yang raya. Barangbarang yang diproduksi oleh kekaisaran dikerjakan oleh tenagatenaga yang terampil sehingga kualitasnya bagus. Namun demikian, seni dalam segala aspeknya (termasuk arsitektur, lukisan, batu giok, dan keramik) masih dikerjakan secara tradisional. Masuknya teknologi dan seni dari barat akan memiliki dampak yang signifikan pada pengembangan industri keramik (Li, tt: 263).

Masih terkait dengan temuan keramik, terdapat tiga kelereng. Masing-masing berukuran, kelereng Imempunyai ketebalan 1,62 cm, kelereng II mempunyai ketebalan $1,59 \mathrm{~cm}$, dan kelereng III dengan ketebalan 1,52 cm. Kelereng III dibuat dari bahan yang berbeda dengan kelereng I dan II. Kelereng III ini dibuat dari bahan batu gamping. Pada umumnya kelereng dengan ukuran tersebut di atas berfungsi sebagai alat permainan anak-anak.

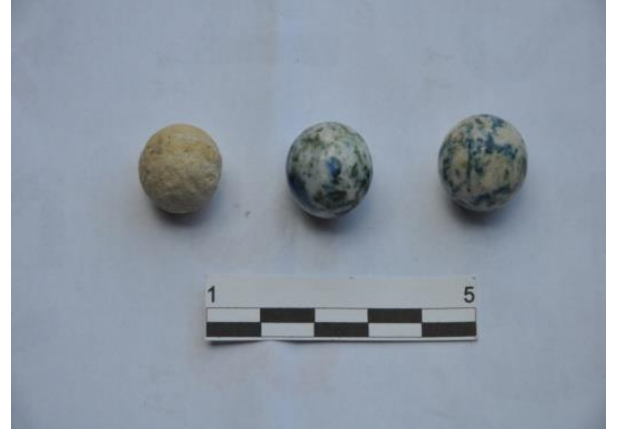

Gambar 9. Kelereng Sebagai Sarana Permainan Anak-Anak

(Sumber: Dokumentasi Penulis)

Keberadaan keramik asing yang ditemukan di Kauman ini kemungkinan dapat menggambarkan suatu keadaan pada masa lalu, yaitu bahwa masyarakat Kauman pada waktu itu selain menggunakan barang-barang lokal juga menggunakan barang-barang yang berasal dari negara lain, yaitu Cina dan Belanda (Eropa). Berdasarkan atas data-data yang ditemukan terdapat beberapa macam benda atau barang dari keramik asing yang pernah digunakan oleh masyarakat Kauman pada waktu itu, yaitu terdiri atas mangkuk kecil, piring, mangkuk, cangkir, gelas, piring kecil, tutup cangkir, teko, tutup wadah, dan botol. Barang-barang tersebut merupakan peralatan rumah tangga. Mangkuk kecil merupakan benda yang digunakan untuk minum teh pada masyarakat Jepang. Piring merupakan peralatan makan, mangkuk berfungsi sebagai tempat sayuran, cangkir dan gelas berfungsi sebagai tempat minum, piring kecil merupakan "tatakan" yang salah satu fungsinya sebagai tempat untuk meletak cangkir dan gelas, teko berfungsi sebagai tempat air minum, dan botol Eropa di negara asalnya berfungsi sebagai tempat air soda.

Terakhir adalah temuan kaca. Secara fisik temuan jenis ini dikelompokkan menjadi dua, yaitu utuh dan tidak utuh. Temuan utuh 
berupa botol. Botol ini berwarna hijau muda. Setelah dilakukan pengukuran isi (volume) diketahui bahwa botol ini berkapasitas cairan sebanyak $300 \mathrm{ml}$. Kapasitas sebanyak ini termasuk dalam katagori sedang, tidak besar dan tidak kecil. Pada umumnya botol dengan ukuran sebesar ini digunakan sebagai tempat untuk menampung minyak ataupun kecap.

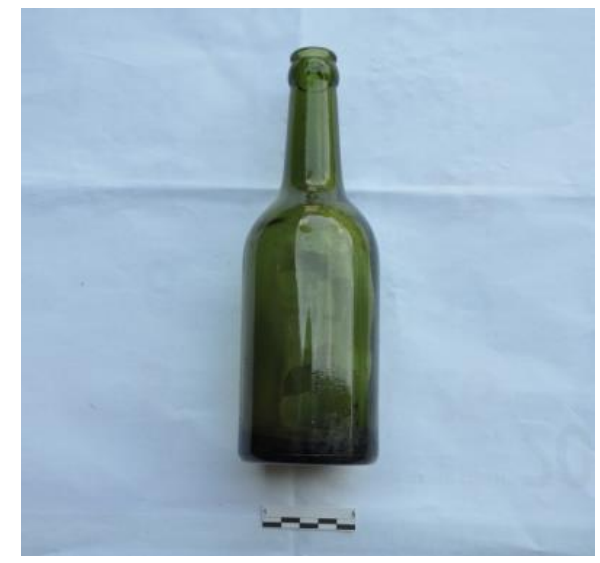

Gambar 10. Botol Berwana Hijau Muda dengan Volume $300 \mathrm{ml}$

(Sumber: Dokumentasi Penulis)

Selain itu terdapat 4 fragmen kaca berwarna putih transparan dan dari hasil analisis diketahui bahwa keempat fragmen tersebut berasal dari bentuk kap lampu gantung.

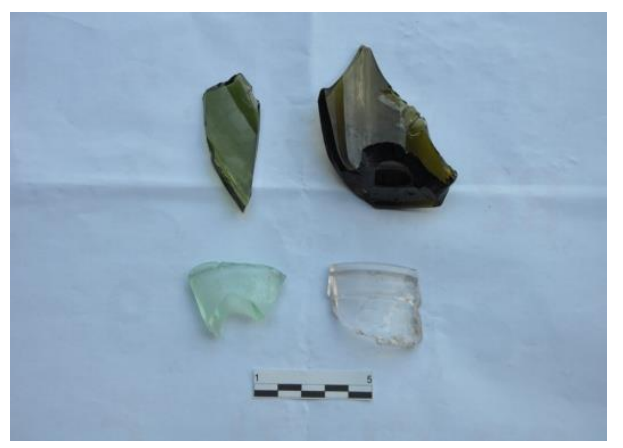

Gambar 11. Fragmen Kaca Berasal Dari Bentuk Botol

(Sumber: Dokumentasi Penulis)

Selanjutnya temuan kaca yang tidak utuh terdiri atas tiga warna, yaitu putih transparan, hijau muda transparan, dan biru muda transparan. Berdasarkan atas analisis bentuk, diketahui bahwa fragmenfragmen tersebut berasal dari bentuk botol. Selain itu terdapat pula temuan 1 fragmen kaca berwarna putih transparan dengan ketebalan antara 1 - 1,04mm dan bagian bawah (dasar) bulat. Melihat bentuk dan ukuran yang demikian ini, dari hasil analisis diketahui bahwa fragmen ini mengingatkan kepada semprong lampu minyak. Pada umumnya lampu minyak yang demikian ini diletakkan pada dinding tembok rumah tinggal.

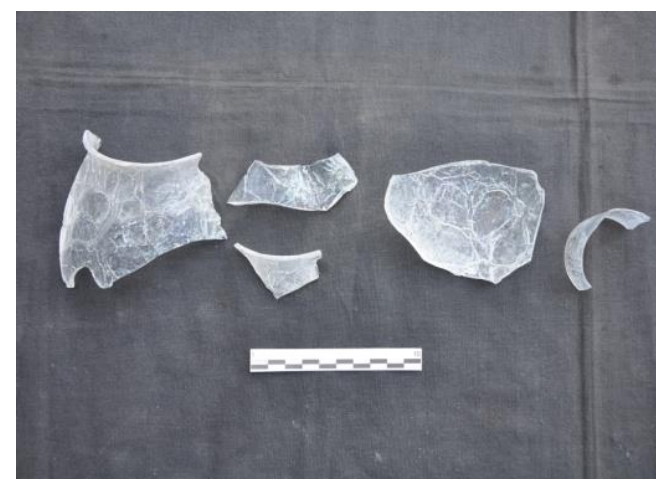

Gambar 12. Empat Fragmen Kaca di Sebelah Kiri Merupakan Kap Lampu Gantung, Satu Fragmen Kaca di Sebelah Kanan Merupakan "Semprong" Lampu Minyak

(Sumber: Dokumentasi Penulis)

Berdasarkan data yang berupa fragmen kaca di atas, terdapat tiga macam benda atau barang yang pernah digunakan masyarakat Kauman. Ketiga benda tersebut adalah botol, kap lampu, dan semprong. Botol berfungsi sebagai tempat menampung minyak atau kecap, kap lampu merupakan bagian dari lampu gantung, dan semprong merupakan bagian dari lampu minyak yang ditempatkan di dinding rumah.

Hasil analisis temuan artefaktual seperti tersebut di atas secara umum dapat dipilah menjadi dua, yaitu wadah dan non-wadah. Temuan data yang berupa wadah terdiri atas kendi, kuali atau 
pengaron, mangkuk kecil, mangkuk, piring, cangkir, gelas, tatakan cangkir, tutup cangkir, teko, tutup wadah, dan botol. Adapun temuan yang berupa non wadah terdiri atas figurin, kelereng, kap lampu gantung, dan semprong lampu minyak. Data-data tersebut merupakan salah satu indikasi tentang adanya permukiman, sebab benda-benda tersebut merupakan peralatan kebutuhan sehari-hari. Dari data tersebut dimungkinkan bahwa kawasan atau lokasi ditemukannya artefak tersebut merupakan permukiman lama. Selanjutnya yang menjadi pertanyaan adalah kapan permukiman tersebut berlangsung.

Untuk dapat mengetahui kronologi tersebut, secara umum yang digunakan adalah data fragmen keramik (khususnya keramik Cina). Seperti telah diutarakan di atas, keramik dari Cina tersebut berasal dari Dinasti Ming (1368 - 1644 M) dan Dinasti Qing (1644 - awal abad 20). Jikalau lokasi ditemukannya artefak-artefak itu dikaitkan dengan Dinasti Ming (1368 - 1644 M) maka kronologinya terlalu tua. Sebab jika permukiman Kauman itu keberadaannya dikaitkan dengan pendirian Masjid Besar Kauman yaitu $1773 \mathrm{M}$ (pendirian ruang inti) dan $1775 \mathrm{M}$ (pendirian serambi). Kronologi tersebut merupakan masa pemerintahan Sultan Hamengku Buwana I (1775 - 1792 M) (Chawari, 1989: 89 - 94). Sementara itu, jika permukiman itu dikaitkan dengan Dinasti Qing (1644 - awal abad 20) maka kronologinya bisa dipahami karena semasa. Oleh karena itu yang menjadi pertanyaan bagaimana dengan kronologi yang berasal dari fragmen keramik Cina dari masa Dinasti Ming (1368 - 1644 M)? Berdasarkan atas uraian di atas terdapat dua catatan penting, yaitu: a). Fragmen keramik merupakan benda yang bersifat artefaktual, yaitu benda yang mudah dipindahkan; b). Terlalu dini untuk mengatakan bahwa terdapat permukiman lama praKauman sekarang.

Sementara itu terdapat kronologi lain yaitu berdasarkan data dari fragmen keramik Eropa, yaitu dari pabrik milik Petrus Regout. Keramik ini berasal dari tahun 1836 1969 (sekitar pertengahan abad XIX - pertengahan abad XX). Jika kronologi ini dikaitkan dengan pendirian Masjid Besar Kauman, maka tahun 1836 (tahun pendirian pabrik keramik Petrus Regout) adalah kurang lebih sekitar setengah abad setelah pendirian masjid tersebut. Tahun tersebut (1836) merupakan masa pemerintahan Sultan Hamengku Buwana V (1823 - 1855 M) (Chawari, 1989: lampiran tabel). Sementara tahun 1969 (tahun berakhirnya pabrik keramik Petrus Regout) merupakan masa pemerintahan Sultan Hamengku Buwana IX (1940 - 1988 M) (Chawari, 1989: lampiran tabel).

\section{KESIMPULAN}

Berdasarkan hasil uraian seperti tersebut di atas dan juga analisis arkeologis terhadap temuan data non-monumental atau data artefaktual dapat disimpulkan informasi penting untuk menjawab permasalahan yang telah dikemukakan di depan. Temuan artefaktual yang terdiri atas gerabah, fragmen keramik, dan fragmen kaca dapat memberikan gambaran tentang situasi yang ada pada waktu itu di suatu tempat tertentu. Demikian pula dengan temuan artefaktual yang ada di Kampung Kauman Yogyakarta. Temuan-temuan tersebut dapat memberikan gambaran bahwa lokasi Kampung Kauman dan sekitarnya 
dahulu diduga merupakan suatu kawasan permukiman lama.

Secara rinci temuannya berupa:

1. Gerabah, terdiri atas kendi (salah satu fungsinya sebagai tempat air minum), kuali atau pengaron (tempat air bersih), dan cobek (tempat untuk membuat sambal). Temuan lain adalah fragmen figurin (hiasan atau dekorasi dalam rumah).

2. Fragmen Keramik. Berdasarkan asal usulnya yaitu keramik Jepang, Eropa, dan Cina. Keramik Jepang berupa mangkuk kecil yang digunakan untuk minum teh. Keramik Eropa berupa piring (peralatan dan tempat makan), mangkuk (tempat sayuran), cangkir dan gelas (peralatan tempat minum), piring kecil atau tatakan (tempat meletakkan cangkir dan gelas), tutup cangkir, teko (tempat air minum), tutup wadah, botol Eropa (tempat air soda), dan kelereng. Khusus kelereng mempunyai fungsi praktis yaitu sebagai alat permainan anakanak. Sedangkan keramik asing lainnya adalah keramik Cina yang berupa piring, mangkuk, dan mangkuk kecil.

3. Fragmen Kaca, terdiri atas botol (tempat menyimpan minyak atau kecap), kap lampu gantung, dan semprong lampu minyak.

Dari uraian di atas diketahui bahwa benda-benda dari gerabah, keramik, dan kaca yang ditemukan di Kampung Kauman Yogyakarta merupakan barang-barang kebutuhan sehari-hari yang pernah digunakan oleh masyarakat Kauman pada waktu itu. Selain itu benda-benda tersebut menjadi bukti dinamika kehidupan yang berlangsung di Kampung Kauman pada masa lalu.

\section{UCAPAN TERIMA KASIH}

Ucapan terima kasih ini ditujukan kepada para pekerja yang membangun rumah di Kauman Gm I No. 244, Kelurahan Ngupasan, Kecamatan Gondomanan, Yogyakarta. Terdiri atas enam orang pekerja, yaitu: Bp. Saryanto, Bp. Pairan, Bp. Ngatijan, Bp. Riswanto, Bp. Yunianto, dan Bp. Jarot Sudarmaji. Keenam orang tersebut beralamat di Dusun Beji, Desa Sumberagung, Kecamatan Jetis, Kabupaten Bantul, Daerah Istimewa Yogyakarta. Ucapan terima kasih ini terkait dengan usaha mereka dalam mengumpulkan dan menyelamatkan data arkeologis yang bersifat artefaktual dan terdiri atas: fragmen keramik, fragmen gerabah, dan fragmen kaca. 


\section{DAFTAR PUSTAKA}

Abbas, Novida. 2016. "Laporan Penelitian Arkeologi: Identifikasi Potensi dan Pengelolaan Sumberdaya Arkeologi Di Kawasan Kota Lama Semarang (Tahap IX)", Yogyakarta: Balai Arkeologi.

Adhyatman, Sumarah. 1990. Antique Ceramics Found in Indonesia. Jakarta: Ceramic Society on Indonesia.

Anonim. 1994. Penelitian Arkeologi Dalam Siklus Pengelolaan Benda Cagar Budaya. Yogyakarta: Balai Arkeologi.

Chawari, Muhammad. (1989). "Pasang Surut Masa Perkembangan Pembangunan Masjid Besar Kauman Yogyakarta: Studi Berdasarkan Sumber Prasasti". Universitas Gadjah Mada.

. (2008). "Bangunan Rumah Tradisional Jawa Di Kampung Kauman Yogyakarta, Sebuah Model Pengelolaan". Tesis Master. Program Studi Arkeologi, Jurusan IImu-ilmu Humaniora. Yogyakarta: Universitas Gadjah Mada.

Li, He. Tt. Chinese Ceramics: The New Standard Guide. Singapore: Thames and Hudson.

Mulyati, Ahda. (1995). "Pola Spasial Permukiman Di Kampung Kauman Yogyakarta”. Universitas Gadjah Mada.

Ratna, Nyoman Kutha. 2010. Metodologi Penelitian: Kajian Budaya dan IImu Sosial Humaniora Pada Umumnya. Yogyakarta: Penerbit Pustaka Pelajar.

Rangkuti, Nurhadi; Inge Pojoh; Naniek Harkantiningsih. 2008. Buku Panduan Analisis Keramik. Jakarta: Pusat Penelitian dan Pengembangan Arkeologi Nasional.

Shadily, Hassan. 1980. Ensiklopedi Indonesia (Buku 2). Jakarta: Penerbit Buku Ichtiar Baru - Van Hoeve.

1982. Ensiklopedi Indonesia (Buku 3). Jakarta: Penerbit Buku Ichtiar Baru - Van Hoeve.

1983. Ensiklopedi Indonesia (Buku 4). Jakarta: Penerbit Buku Ichtiar Baru - Van Hoeve.

Suwito, Yuwono Sri. "Mengenal Sumbu Imajiner Dan Sumbu Filosofi Kraton Yogyakarta". Buletin Pelestarian Warisan Budaya dan Cagar Budaya Edisi 2, 2016.

Tanudirjo, Daud Aris. 1988 - 1989. Laporan Penelitian Ragam Metoda Penelitian Arkeologi Dalam Skripsi Karya Mahasiswa Arkeologi Universitas Gadjah Mada. Yogyakarta: Fakultas Sastra Universitas Gadjah Mada. 
Triatmodjo, Suastiwi. (2010). "Pemufakatan Dan Desakralisasi Ruang Di Permukiman Kauman Yogyakarta”. Universitas Gadjah Mada. 